\title{
Valorization of Brewers' Spent Grains: Pretreatments and Fermentation, a Review
}

\author{
Sara Mitri ${ }^{1,2, *}$, Sarah-Joe Salameh ${ }^{1}$, Anissa Khelfa ${ }^{1}$, Estelle Leonard ${ }^{1}$ (D) Richard G. Maroun $^{2}$, \\ Nicolas Louka ${ }^{2}$ (D) and Mohamed Koubaa ${ }^{1, *(\mathbb{D})}$
}

1 TIMR (Integrated Transformations of Renewable Matter), Université de Technologie de Compiègne, ESCOM, Centre de Recherche Royallieu, CS 60 319, CEDEX, 60203 Compiègne, France; sarahjoesalameh22@gmail.com (S.-J.S.); a.khelfa@escom.fr (A.K.); e.leonard@escom.fr (E.L.)

2 Laboratoire CTA, UR TVA, Centre d'Analyses et de Recherche, Faculté des Sciences, Université Saint-Joseph, Beyrouth 1104 2020, Lebanon; richard.maroun@usj.edu.lb (R.G.M.); nicolas.louka@usj.edu.lb (N.L.)

* Correspondence: sara.mitri@net.usj.edu.lb (S.M.); m.koubaa@escom.fr (M.K.)

check for updates

Citation: Mitri, S.; Salameh, S.-J.; Khelfa, A.; Leonard, E.; Maroun, R.G.; Louka, N.; Koubaa, M. Valorization of Brewers' Spent Grains: Pretreatments and Fermentation, a Review. Fermentation 2022, 8, 50. https://doi.org/10.3390/ fermentation 8020050

Academic Editor: Sathyanarayanan Sevilimedu Veeravalli

Received: 23 December 2021

Accepted: 21 January 2022

Published: 25 January 2022

Publisher's Note: MDPI stays neutral with regard to jurisdictional claims in published maps and institutional affiliations.

Copyright: (c) 2022 by the authors. Licensee MDPI, Basel, Switzerland. This article is an open access article distributed under the terms and conditions of the Creative Commons Attribution (CC BY) license (https:// creativecommons.org/licenses/by/ $4.0 /)$.

\begin{abstract}
Brewers' spent grains constitute a valuable byproduct of the beer industry. They are characterized by a rich nutritional composition consisting of around $70 \%$ lignocellulosic fibrous material, $20 \%$ proteins, $10 \%$ lipids, in addition to vitamins, minerals, amino acids, and phenolic compounds. These spent grains are produced in large amounts all through the year, are cheap, and lack economically feasible applications. Nowadays, $70 \%$ of these spent grains are used as animal feed, $10 \%$ are used for biogas production, and the remaining $20 \%$ are disposed in landfills. Due to the aforementioned facts, alternative uses of the brewers' spent grains are highly sought-after. In fact, this nutrient-rich industrial by-product makes it a very good candidate for valorization through biotechnological processing, particularly microbial fermentation. After applying the needed pretreatments, using brewers' spent grains as a substrate in submerged and solid-state fermentation of different microorganisms leads to the production of various value-added compounds such as organic acids, amino acids, volatile fatty acids, enzymes, vitamins, second-generation biofuels and other products.
\end{abstract}

Keywords: brewers' spent grains; agro-industrial byproducts; valorization; pretreatments; biotechnology; submerged fermentation; solid-state fermentation; high value-added compounds

\section{Introduction}

Beer is one of the oldest and most consumed alcoholic drinks worldwide. It is the third most popular beverage after water and tea [1]. The brewing process involves a set of treatment steps of the initial barely grains, including malting, milling, mashing, lautering, boiling, wort cooling, and fermenting. Like other manufacturing processes, industrial beer production predictably produces waste and by-products. After the mashing of barley starch, the insoluble solid fraction of the grains, known as Brewers' spent grains (BSG), is filtered from the wort, which is the sweet liquor that will be fermented into beer [2]. BSG comprises the seed coat (testa), husk, and the pericarp layers that covered the original barley grains. In fact, BSG account for $85 \%$ of the total solid residues generated during the brewing process and 30\% of the initial malt weight [3]. In 2018, around 1.94 billion hectoliters (hL) of beer were manufactured worldwide, out of which 406 million hL were produced in the European Union. According to the annual beer statistics report of 2019, Germany is the leading beer producing country, followed by Poland, United Kingdom, and Spain. It is noteworthy that for every $100 \mathrm{~L}$ of beer produced, around $20 \mathrm{~kg}$ of wet BSG are obtained as by-products [4,5].

This by-product is known to contain considerable amounts of valuable compounds that are unaltered during the brewery process [6]. However, the chemical composition of BSG depends on the type of barley grains, the harvesting time, the brewing technology, and the 
process parameters used [7]. Despite this variability, BSG mainly consist of lignocellulosic fibrous material and relatively high protein content corresponding to $70 \%$ and $20 \%$ of dry basis, respectively [8]. The fiber part is composed of around $28.35 \%$ hemicellulose, $16.25 \%$ cellulose, and $7.27 \%$ lignin, all of which provide resistance to the degradation of the BSG [6]. Various monosaccharides, oligosaccharides, and polysaccharides are present in BSG. The most abundant monosaccharides in BSG are glucose, xylose, and arabinose. The most common proteins present are hordeins, glutelins, globulins, and albumins. Moreover, $10 \%$ of BSG consist of lipids, of which triglycerides have a higher percentage, followed by free fatty acids [6,9]. BSG also contains amino acids, vitamins, minerals, and phenolic compounds. Particularly, phenylalanine, lysine, tryptophan, histidine, and methionine are the essential amino acids that are present in BSG, whereas alanine, glycine, proline, and serine are the non-essential ones. A wide range of vitamins have been reported in BSG; namely, biotin, choline, pantothenic acid, folic acid, niacin, riboflavin, thiamine, and pyridoxine. In addition, phosphorus, calcium, cobalt, potassium, copper, iron, magnesium, manganese, selenium, sulphur, and sodium are the minerals present in BSG. It is worth mentioning that ferulic acid and p-coumaric acid are the major phenolic compounds present in BSG [10].

Due to its high moisture content, which is around $80 \%$, along with its richness in polysaccharides and proteins, BSG is highly prone to microbial contamination, and hence has a very short lifespan (between 7 and 10 days) [6]. These characteristics have various impacts on different levels. At the environmental level, BSG present a high risk if disposed without a required treatment. In fact, in a landfill, every ton of BSG releases around $514 \mathrm{~kg}$ $\mathrm{CO}_{2}$ greenhouse gases equivalent. Therefore, BSG lead to high waste generation and bad environmental effects [11]. At the level of spent grains, the aforementioned characteristics render the transportation of BSG expensive, their storage difficult, and limit their stability and exploitation [12]. Currently, 70\% of the BSG are used in animal feed such as cattle, poultry, and chicken, while $10 \%$ are used for biogas production, and the remaining $20 \%$ are disposed in landfills [11]. Due to the interesting nutritional constituents of BSG, recent studies are suggesting incorporating it in some food products and hence in the human diet. A limited amount of BSG-around 5 to 10\%-has been added to various food products, including bread, cakes, cookies, and egg pasta, in order to avoid affecting the final product properties such as the taste, color, and texture [3].

To overcome BSG aggregation-related issues, and to minimize the waste and pollution arising from the brewing industry, an alternative valorization route through biotechnological processing is highly sought-after. In addition to the nutritional value of the spent grains, their availability throughout the year at a very low cost-equivalent to 40.23 USD per ton of BSG-makes them a favorable raw material for various potential applications $[13,14]$. Particularly, microbial fermentation is a promising biovalorization method for this highvolume industrial byproduct [2]. For instance, it was reported that this cheap feedstock was used to naturally produce the valuable aromatic compound 2-phenylethanol through microbial fermentation mainly using yeasts, competing with the conventional, environmentally unfriendly, chemical synthesis routes [15]. A simplified scheme of the brewing process, BSG constituents, and their uses, is illustrated in Figure 1.

In this review, the biotechnological valorization of the BSG will be discussed. The various pretreatment methods applied for BSG to disrupt the natural resistance of the lignocellulose and to prepare the substrate for microbial activity - making it more accessible-were introduced. Then, submerged fermentation and solid-state fermentation methods were defined and discussed. The multiple value-added compounds produced via both types of fermentation were also described. 


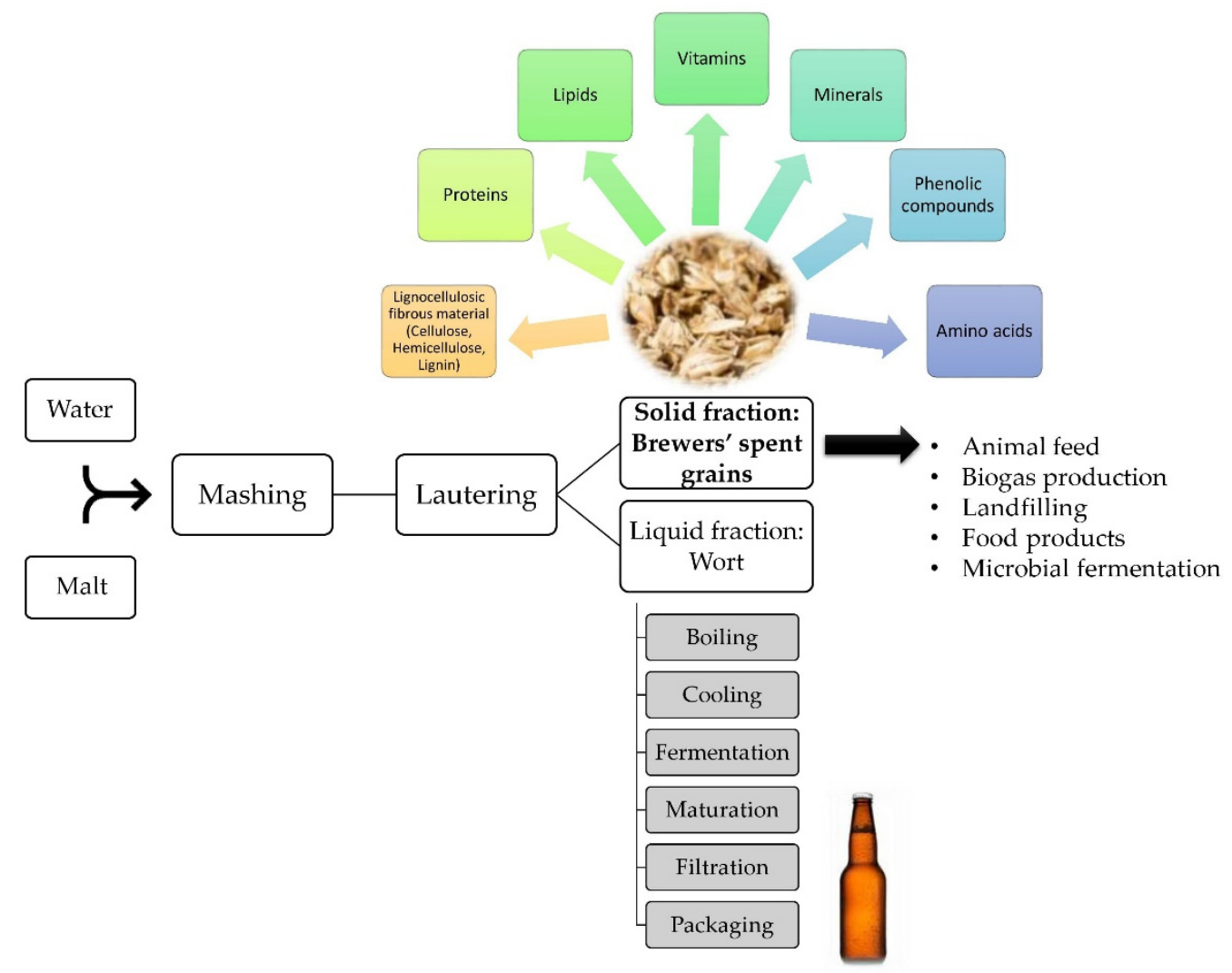

Figure 1. Simplified scheme of the brewing process, focusing on the brewers' spent grains, their composition and utilization $[2,10,11]$.

\section{Pretreatment Methods of Brewers' Spent Grains}

As previously mentioned, BSG composition allows the formation of value-added products. However, due to the complicated natural plant cell wall composition, including cellulose, hemicellulose, and lignin, which interlock together to form a recalcitrant structure, the utilization of lignocellulosic materials in biorefinery processes require a pretreatment that disrupt their crystalline structure and allow their fractionation [16]. Effectively disrupting the rigid structure of lignocellulose releases and exposes the locked polysaccharides, after which they can be saccharified more easily by the action of the cellulolytic enzymes, hence maximizing the release of sugars upon enzymatic hydrolysis [17]. Therefore, breaking down the spent grains into their constituents will yield a number of value-added components including carbohydrates and proteins, which constitute a suitable medium or substrate for the fermentative production of various bioactive compounds [18]. Consequently, pretreatments will prepare the lignocellulosic substrate for microbial activity, making it more accessible to the microbial consortium [19]. These pretreatments will break cellulose into glucose and hemicellulose into mainly xylose and arabinose, which are the most abundant monosaccharides present in the hydrolyzed spent grains [20]. Prior to enzymatic hydrolysis, a pretreatment step is applied to the BSG. Pretreatments can be classified into chemical (e.g., alkaline, acid, organosolv pretreatments, and ionic liquids), physical (e.g., mechanical, hydrothermal, ultrasonic, and microwave radiation pretreatments), biological (using fungi or bacteria), and hybrid pretreatment methods such as physicochemical pretreatments [21]. A summary of the various types of pretreatments is presented in Figure 2. 


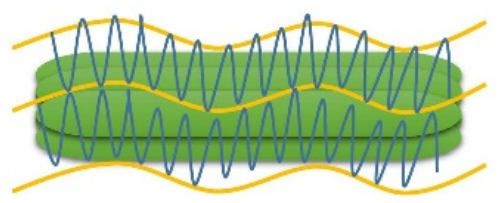

Brewers' spent grains lignocellulosic biomass

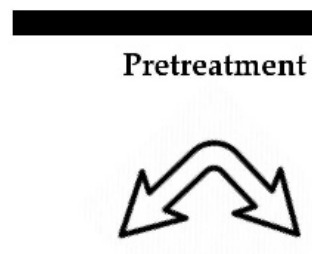

Cellulose

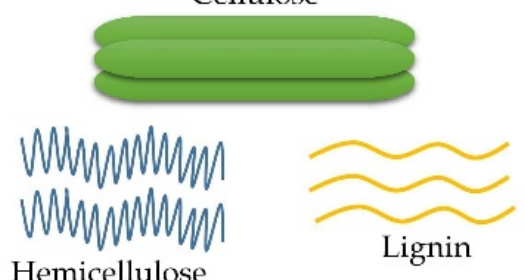

Hemicellulose
Lignin
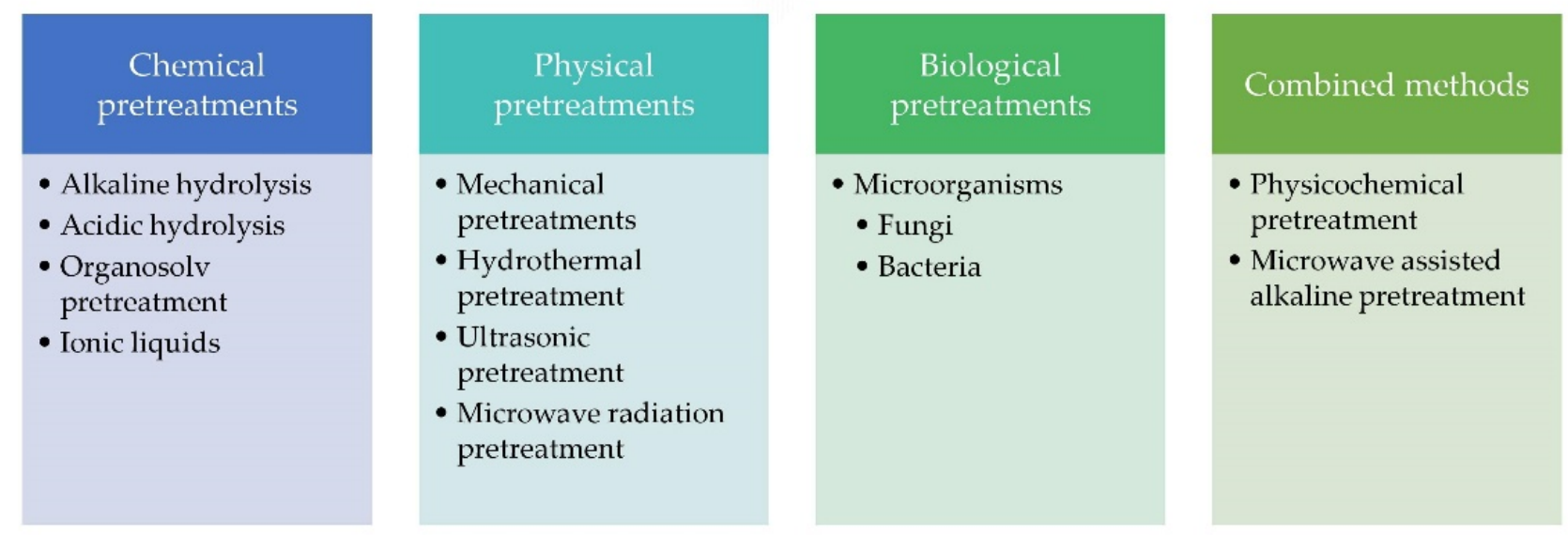

Figure 2. Lignocellulosic biomass pretreatment methods [21,22].

Chemical pretreatments' efficacy and the mode of action vary with the $\mathrm{pH}$. One of the most commonly used pretreatments is the use of acidic solutions, such as sulfuric acid, using either low acid concentration, less than 5\%, a high temperature, between 120 and $210^{\circ} \mathrm{C}$, and a pressure less than $10 \mathrm{~atm}$, or a concentrated acid, less than $30 \%$, a temperature less than $100{ }^{\circ} \mathrm{C}$, and at atmospheric pressure [9]. Acidic pretreatments are based on the sensitivity of the glycosidic bonds between hemicellulose and cellulose to acid [22]; hence, they aim to enhance the efficiency of recovering cellulose and xylose [23]. On the other hand, other chemical pretreatments use alkaline reagents, such as sodium, calcium, and potassium hydroxides. The latter solutions work by removing lignin, and, to a lesser extent, hemicellulose from the lignocellulosic material of BSG, which facilitates the access of the enzymes to it. In fact, a saponification reaction occurs during this type of pretreatment, leading to the cleavage of intermolecular ester linkages between hemicelluloses and lignin. Alkaline reagents also act through a swelling mechanism, which increases the porosity and internal surface of the biomass [24]. The conditions of alkaline pretreatments are usually less severe compared to other types of pretreatments. They can be done at room temperature but to a longer pretreatment time compared to higher temperatures [25]. A study done on BSG reported that the enzymatic hydrolysis of acid and alkali pretreated BSG has doubled the hydrolysis compared to the untreated sample. Yet the nature of the solubilized sugars was different. The amount of reducing sugars (monosaccharides) obtained from the enzymatic hydrolysis of $\mathrm{H}_{2} \mathrm{SO}_{4}$ pretreated $\mathrm{BSG}$ was much higher ( $66 \%$ for $0.5 \mathrm{~N} \mathrm{H}_{2} \mathrm{SO}_{4}$ ) than the one obtained from the hydrolysis of the $\mathrm{NaOH}$ pretreated sample $(35 \%$ for $0.5 \mathrm{~N}$ $\mathrm{NaOH}$ ) [26]. Alkaline pretreatments have various advantages including usage of cheap chemicals, mild reaction conditions, effective removal of lignin, and low inhibitor formation, and some disadvantages-namely, the long processing time, difficulties in neutralization of the mixture post-treatment, and alteration in lignin structure [27]. On the other hand, acidic pretreatments produce high glucose yield and solubilize hemicellulose, despite the high acid cost. Additionally, this pretreatment method leads to the formation of toxic byproducts such as hydroxymethylfurfural (HMF), furfural, and acetic acid [25,27]. In the presence of these inhibitors, an extra detoxification step is needed prior to enzymatic hydrolysis and 
fermentation [28]. Furthermore, alkaline hydrogen peroxide (AHP) pretreatment is another chemical pretreatment method. This method uses a combination of hydrogen peroxide and sodium hydroxide solutions at $\mathrm{pH}$ 11.5. It is effective for the delignification and solubilization of hemicellulose. AHP pretreatments are characterized by modest reaction conditions and low usage of alkali [24]. Additionally, organosolv pretreatment method uses various organic or aqueous solvent mixtures in order to solubilize hemicellulose and extract lignin. Actually, these solutions break down the internal bonds between lignin and hemicellulose. A wide range of organic solvents might be used in this method, some of which are methanol, ethanol, acetone, ethyl glycol, and organic acids. The optimal temperature of the organosolv pretreatment method is between 100 and $250{ }^{\circ} \mathrm{C}$. A catalyst is usually added in this process to either improve the delignification rate or decrease the pretreatment temperature [22]. Finally, there is an increasing interest in the usage of ionic liquids (ILs) as pretreatment methods. In ILs pretreatments, both cations and anions play an important role in solubilizing cellulose and lignin. ILs are characterized by their low vapor pressure, non-toxicity, non-volatility, large thermal and chemical stability, and most importantly their recoverability and reusability [29].

On the other hand, various physical pretreatment methods could be applied in order to disrupt the lignocellulosic structure of BSG and release its valuable constituents, making it more accessible to enzymes. In fact, physical pretreatments are suitable for products that are destined for use in food [30], starting with mechanical pretreatments, such as milling and blending, which reduces the BSG into small fragments. Then, followed by enzymatic treatment, Beldman et al. reported that these two techniques yielded a $10 \%$ increase in the monosaccharides present in BSG derived from cellulose and hemicellulose hydrolysis, indicating an improve in the susceptibility to the enzymatic hydrolysis [26]. Another example of physical pretreatment methods is hydrothermal pretreatments. The deconstruction process in this method is referred to as autohydrolysis, since the water content of the BSG acts to disrupt the lignocellulosic structure and to hydrolyze the hemicellulose, prior to the subsequent enzymatic hydrolysis. Hydrothermal pretreatments do not use hazardous and costly chemicals, but they require harsh operating conditions, particularly a high temperature, ranging between 120 and $200^{\circ} \mathrm{C}$, to attain satisfactory degradation. The addition of a catalyst - namely, a diluted strong acid-was reported to improve the efficiency of this process and to permit the usage of a lower temperature [17]. It is noteworthy that several toxic byproducts are produced during this method. A study done by Gomes et al. reported that hydrothermolysis led to a $10 \%$ increase in methane production from BSG. Particularly, $467.6 \mathrm{NmL} / \mathrm{g}$ methane was produced by a pretreated sample (hydrothermolysis at $140{ }^{\circ} \mathrm{C}$ for $15 \mathrm{~min}$ ) compared to $409.8 \mathrm{NmL} / \mathrm{g}$ produced by the unpretreated sample [19]. Finally, ultrasonic pretreatment holds potential for large-scale processes. It enables a major decrease in time and energy when compared to alkaline extraction [30]. Ultrasonic pretreatment occurs in liquid media, resulting in cavitation phenomena. In this phenomenon, microbubbles are formed, grow, and then at a critical size they aggressively collapse, converting sonic into mechanical energy. The latter cavitation effect produces high temperature and pressure, in addition to shear forces, which lead to the creation of the "hot-spot effect" in the liquid and the formation of free radicals. The preciously described phenomenon aids in decreasing the crystallinity of the cellulose and increasing the surface area of the BSG, making it more accessible to the enzymatic hydrolysis. BSG pretreatment, under the optimal ultrasonication conditions, led to a 2.1 fold increase in sugar yield, compared to the unpretreated BSG [31].

Moving to hybrid methods, physicochemical and microwave-assisted alkaline pretreatment methods will be discussed. Steam explosion [32], ammonia fiber explosion (AFEX) [33], $\mathrm{CO}_{2}$ explosion pretreatment [34], and liquid hot water (LHW) [35] are various examples of physicochemical pretreatments. They affect the physical parameters, as well as the chemical bonds and intermolecular interactions of the lignocellulosic materials [36]. Additionally, microwave-assisted alkali pretreatment is another hybrid approach. The 
application of microwave radiation in the presence of alkali solution $(0.5 \mathrm{M} \mathrm{NaOH})$ for $10 \mathrm{~min}$ at $160^{\circ} \mathrm{C}$, liberated $49 \%$ of the polysaccharides present in BSG [30].

Finally, biological pretreatments require microorganisms, mainly fungi or bacteria, for the treatment of lignocellulosic material and degradation of hemicellulose, lignin, and sometimes cellulose, depending on the microorganism used. Mainly white-rot fungi are involved in this type of pretreatment, due to the high sugar yield associated with enzymatic hydrolysis. Since they carry lignin degrading enzymes, white-rot usually degrades lignin. In fact, brown-rot degrades cellulose whereas white- and soft-rot fungi target lignin and cellulose. Biological pretreatment method is environmentally friendly, consumes less energy, involves mild conditions, and is not costly; however, it is very slow (low rate of hydrolysis) and requires careful control of growth conditions, as well as much space to perform the pretreatment [21,29].

As previously mentioned, pretreated susceptible spent grains are then subjected to enzymatic saccharification. A wide range of enzymes might be used in order to complete the hydrolysis, including xylanases, acetyl esterases, glucuronidases, $\beta$-xylosidases, feruloyl esterases, glucuronoyl esterases and $\alpha$-L-arabinofuranosidases, which can be targeted toward specific products [37]. Enzymatic hydrolysis process displays some advantages, including mild process requirements, low energy consumption, high sugar yields, and no production of unwanted waste products [38]. Finally, it is noteworthy that no pretreatment has a $100 \%$ conversion rate [9].

\section{Brewers' Spent Grains Fermentation and Production of Value-Added Compounds}

The production of high value-added bio-products using microorganisms, mainly bacteria and fungi, has been a trending headline in the biotechnological industry. Particularly, using biomass from agro-industrial waste materials as a substrate in these biotechnological applications, to produce microbial cell biomass and to grow different fungi without the need for extra nutrients, has been at the center of attention [8]. Due to the high nutritional value of BSG, mainly its high hemicellulose content ranging between 19 and $42 \%$ [19], this secondary raw material can produce through fermentation several value-added products, such as organic acids, amino acids, volatile fatty acids, enzymes, vitamins, second-generation biofuels and other products [23,39]. For instance, a study done by Marcus and Fox reported that BSG can be processed into various enzymes, including $\alpha$-amylase, $\beta$-amylase, cellulases, glucanases, hemicellulases, etc., and to other products such as xylitol, bioethanol, and citric acid through fungal fermentation of BSG [40]. Other value-added products are reported in this review-namely, L-lactic acid, $\beta$-xylosidase and $\alpha$-L-arabinofuranosidase, 2-phenylethanol (2-PE), gibberellic acid (GA3), using not only fungal fermentation but also bacterial fermentation of BSG. Additionally, it is noteworthy that recent studies have reported that this valuable by-product can be biovalorized into natural pigments, namely monascus red pigment, which has been used as a natural coloring agent and food additive in East Asia, hence broadening the applications and importance of this industrial nutrient-rich byproduct [41].

Two types of fermentation might be used in the valorization process of BSG. In the next section, both submerged and solid-state fermentation processes will be discussed along with the various value-added products that can be produced via both types of fermentation.

\subsection{Submerged Fermentation}

\subsubsection{Introduction about Submerged Fermentation}

Submerged fermentation $(\mathrm{SmF})$ is the classical fermentation type that has been used since the 1940s [42]. In this technique, microorganisms grow in a liquid medium containing the needed nutrients. The quantity of water available for bacterial growth affects the development of biomass, the metabolic reactions, and the mass transfer processes [9]. The free-flowing liquid substrates can be either a synthetic media (broths), a waste, or industrial by-product substrate such as molasses. It is noteworthy that this technique is suitable for microorganisms that usually require high moisture content and for the 
production of secondary metabolites that need to be used in their liquid form since they are usually secreted in the fermentation broth [43]. Due to the numerous advantages of this technique, it is being used by many industries and facilities. Particularly, most of the enzyme-producing facilities use SmF due to better monitoring and ease of handling [44]. Additionally, this technique allows for the precise control of important growth parameters, including temperature, $\mathrm{pH}$, dissolved oxygen, and substrate concentration [45]. SmF is also characterized by its simple downstream processing after fermentation, particularly easy purification of the products [43,46]. This type of fermentation is less susceptible to substrate inhibition compared to other types, hence leading to a high product yield [47]. Scale-up methods and bioreactors for this type of fermentation were well developed; thus, $\mathrm{SmF}$ can be used on an industrial-scale [48]. SmF supports the use of genetically modified organisms [43]. On the other hand, however, it has various disadvantages. For one, it is a time-consuming process where secondary metabolites require time to be produced. Also, it is an energy-consuming process, since $\mathrm{SmF}$ is prone to bacterial and fungal contamination, and requires energy for sterilization. It is a costly process when synthetic media is used as a substrate and expensive raw materials are added to it. Finally, substrates in SmF are utilized quite rapidly and need to be constantly supplemented with nutrients or replaced [49]. Like any other technique, SmF displays advantages and disadvantages, and its usage depends on the field of application and aim of the experiment [42].

\subsubsection{Valorization of BSG Using Submerged Fermentation}

As previously mentioned, BSG can be used as substrate for the fermentation process and yield various valuable compounds. In this part, the production of various value-added compounds through SmF will be discussed. SmF of BSG using Escherichia coli SL100 can produce ethanol. At first, BSG underwent a phosphoric acid pretreatment in order to recover part of the sugar content (retrieving $80 \%$ of the hemicellulose sugar content in BSG and $35.5 \%$ of the total glucose in BSG). The liquid fraction from the pretreatment was then fermented using an ethanologenic E. coli SL100, which is a strain capable of converting the spent grains' xylose, arabinose, and glucose into ethanol and has a high inhibitor tolerance. $\mathrm{SmF}$ was carried out with $150 \mathrm{~mL}$ of prehydrolysate, for $92 \mathrm{~h}$ at $\mathrm{pH} 6.5,37^{\circ} \mathrm{C}$, and $300 \mathrm{rpm}$. After $55 \mathrm{~h}$, a maximal concentration of ethanol was produced which was equal to $16 \mathrm{~g} / \mathrm{L}$, corresponding to a yield of $0.4 \mathrm{~g}$ of ethanol per $\mathrm{g}$ of sugar in the medium [12].

Moreover, SmF of BSG using Aspergillus niger and Saccharomyces cerevisiae can produce citric acid. A. niger strain was isolated from spoiled orange and $S$. cerevisiae strain was isolated from palm wine samples. Fermentation was performed in $500 \mathrm{~mL}$ Erlenmeyer flasks containing $200 \mathrm{~mL}$ of the fermentation medium and $0.2 \mathrm{~mL}$ of methanol (to enhance the fungal production of citric acid) for 14 days at $30^{\circ} \mathrm{C}$ and $\mathrm{pH}$ 4.5. The highest citric acid concentrations produced were $0.512 \% / \mathrm{v}$ by $A$. niger after $96 \mathrm{~h}$ fermentation, and $0.312 \% / \mathrm{v}$ by S. cerevisiae after 7 days fermentation [50]. Debaryomyces hansenii was also reported to produce ethanol via fermentation on BSG hydrolysates [51].

Additionally, SmF of BSG using Lactobacillus rhamnosus can produce L-lactic acid. Fermentation was carried out at $37^{\circ} \mathrm{C}$ in $300 \mathrm{~mL}$ conical flask containing $100 \mathrm{~mL}$ immobilized lactic acid bacteria (L. rhamnosus NBRC14710), $70 \mathrm{~mL}$ of liquefied BSG that was enzymatically hydrolyzed, and Tween 80 (a growth factor for lactic acid bacteria). After 5 days, L. rhamnosus NBRC14710 produced $19.0 \mathrm{~g} / \mathrm{L}$ L-lactic acid [52].

Furthermore, SmF of BSG using Bacillus sp. KR-8104 can produce $\alpha$-amylase. Traditionally, $\mathrm{SmF}$ is used to produce $\alpha$-amylase on an industrial scale. The fermentation occurred in $250 \mathrm{~mL}$ Erlenmeyer flask containing $50 \mathrm{~mL}$ medium (dextrin, yeast extract, meat extract, $\mathrm{KH}_{2} \mathrm{PO}_{4}$, and $\left.\mathrm{MgSO}_{4} \cdot 7 \mathrm{H}_{2} \mathrm{O}\right), 5 \%(w / v) \mathrm{BSG}$, and inoculated with a $2 \%(v / v)$ bacterial culture at $37{ }^{\circ} \mathrm{C}$ and $180 \mathrm{rpm}$. The maximum production of $\alpha$-amylase was achieved when using a dextrin-free culture medium and it was around 25,255 U/L (Unit of $\alpha$-amylase per $\mathrm{L}$ of fermented culture medium) [49].

In addition, SmF of BSG using Aspergillus fumigatus and Penicillium sp. can produce cellulase. $100 \mathrm{~g}$ of BSG were washed with $250 \mathrm{~mL}$ of distilled water, at room temperature 
and $220 \mathrm{rpm}$ for $2 \mathrm{~h}$. Then, the liquid part was recuperated using centrifugation whereas the solid part (washed BSG) was dried at $70{ }^{\circ} \mathrm{C}$ for $72 \mathrm{~h}$. SmF occurred at $30{ }^{\circ} \mathrm{C}, 220 \mathrm{rpm}$, for $96 \mathrm{~h}$ in a flask containing $80 \mathrm{~g} / \mathrm{L}$ washed BSG and culture medium (containing yeast extract, $\left(\mathrm{NH}_{4}\right) \mathrm{NO}_{3}, \mathrm{KH}_{2} \mathrm{PO}_{4}, \mathrm{~K}_{2} \mathrm{HPO}_{4}$, and $\mathrm{MgSO}_{4}$ ) inoculated with a 3-day precultured fungi. The highest cellulase activity was 0.354 and $0.232 \mathrm{U} / \mathrm{mL}$ for A. fumigatus and Penicillium sp., respectively [53]. Subsequently, various value-added compounds including ethanol, citric acid, L-lactic acid, $\alpha$-amylase, and cellulase, can be produced through fermentation, particularly SmF, of different microorganisms on BSG and its usage as a carbon and nutrient source for their growth.

\subsection{Solid-State Fermentation}

\subsubsection{Introduction about Solid-State Fermentation}

Solid-state fermentation (SSF) is one of the world's oldest microbiological procedures for fermented food preservation and development. SSF, unlike SmF, is the controlled growth and/or cultivation of microorganisms in the absence of water or with a small amount of water for the manufacture of desired products of interest. The solid matrix can be a source of nutrients or simply support impregnated with the nutrients necessary for microbial development [54,55]. According to the history of fermentation technology, this method was largely ignored in developed countries after the 1940s at the expense of SmF technology. Following the development of penicillin in $\mathrm{SmF}$ and due to the importance of penicillin during the 2nd World War, SmF has become a model technology for the production of any substance via fermentation. As a result, researchers focused solely on the SmF, and the SSF was overlooked. The study of SSF systems has continued in isolated areas, and the transformation of steroids with the help of fungi cultures has been described between the years 1950 and 1960. The trend has continued, albeit slowly, and during the 1960s and 1970s, reports on the production of mycotoxins by the SSF became widely known [56]. The second major activity was the production of high-protein animal feed from agricultural waste. Since then, this process has been used extensively, and this trend has accelerated over the last decade [56,57].

Furthermore, SSF is a well-known and well-established bioprocess for improving nutritional profiles and producing enzymes, particularly used for biomass degradation. The bioreactors used in SSF processes, and classified based on design and operation, are tray bioreactors, packed-bed bioreactors, stirred-drum bioreactors and rotating drum bioreactors, gas-solid fluidized beds and various stirred-aerated bioreactors [58]. Choosing the right bioreactor for the SSF process requires an understanding of the microorganism's morphology, as well as consideration of the process parameters (e.g., pH, temperature, support type, aeration, moisture, and water activity).

SSF has the potential to be a good bioprocess for the generation of microbial secondary metabolites from agricultural waste and industrial leftovers. Bagasse, bran, husks, whole pomace, seeds, peels, corn residue, BSG, and other waste products are produced in large amounts and are either underutilized or discarded. Recently, there has been a lot of focus on using the abovementioned materials, as they are readily available and low-cost renewable substrates able to generate a variety of valuable chemicals [59]. This approach has several advantages over $\mathrm{SmF}$, including lower catabolite repression and substrate inhibition, superior enzyme harvests, environmentally friendly, low output waste, low energy consumption, prolonged product steadiness, no discharge of organic waste water, and low production costs [60-62]. In addition, the process is suitable for work with filamentous fungi. It consists of a simple fermentation process with no foam formation and easy to control of bacterial contamination [63].

Moreover, the disadvantages of this technique depend on the type of bioreactor used. Generally, it is hard to control the metabolite temperature during the process. As a result, the temperature will rise to the point where the intended microbial product will be destroyed or the growth and fermentation are entirely stopped [64]. In addition, steady aeration, growth, and kinetic study are still difficult to achieve [63]. 


\subsubsection{Valorization of BSG Using Solid State-Fermentation}

SSF is a valuable technique for the valorization of agro-industrial byproducts-namely, BSG - to produce value-added products [65]. Cellulase and xylanase enzymes can be produced through SSF of $A$. niger on BSG. SSF was carried out in $250 \mathrm{~mL}$ Erlenmeyer flask containing $2 \mathrm{~g}$ of BSG in an enriched medium (composed of $\left(\mathrm{NH}_{4}\right)_{2} \mathrm{SO}_{4}, \mathrm{NaNO}_{3}, \mathrm{KH}_{2} \mathrm{PO}_{4}$, and yeast extract) with a solid to liquid ratio of 3.5:1 (w/v), and an $80 \%$ humidity. The medium was then sterilized and inoculated with $A$. niger CECT 2700 strain acquired from the Spanish collection of type culture. Fermentation occurred at $30^{\circ} \mathrm{C}$ for 7 days without mixing. The highest cellulase activity was $6.23 \mathrm{U} / \mathrm{g}$ of dry substrate (gds) using BSG pretreated with boiling water, whereas the highest xylanase activity was $1400.80 \mathrm{U} / \mathrm{gds}$ obtained using BSG pretreated in an autoclave [66]. Another study reported the ability of A. fumigatus and Penicillium sp. to produce cellulase, using SSF. Cellulase was produced by fermenting $5 \mathrm{~g}$ of washed BSG inoculated with $4 \mathrm{~mL}$ of a 3-day fungi preculture, at $30{ }^{\circ} \mathrm{C}$ for 18 days, and with $73.6 \%$ humidity. The highest cellulase activity was $7.5 \mathrm{U} / \mathrm{gds}$ after 11 days for $A$. fumigatus, whereas Penicillium sp. produced $8.3 \mathrm{U} / \mathrm{gds}$ cellulase after 14 days [53].

In addition, SSF of BSG using Penicillium janczewskii can lead to the production of multiple xylanolytic enzymes, particularly xylanase, $\beta$-xylosidase and $\alpha$-L-arabinofuranosidase. SSF was performed in $250 \mathrm{~mL}$ Erlenmeyer flasks containing $5 \mathrm{~g}$ of dried BSG and Vogel's salt solution, with a $50 \%$ initial moisture, inoculated with $1 \mathrm{~mL}$ of $P$. janczewskii CRM 1348 suspension. SSF was carried out for 7 days at $28^{\circ} \mathrm{C}$. The maximum amounts of xylanase, $\beta$-xylosidase and $\alpha$-L-arabinofuranosidase produced were $370 \mathrm{U} / \mathrm{gds}, 246.5 \mathrm{mU} / \mathrm{gds}$, and $606.7 \mathrm{mU} / \mathrm{gds}$, respectively [67].

Laccase enzyme can also be produced through the biovalorization of BSG using Trametes versicolor TV-6. $50 \mathrm{~g}$ of BSG mixed with $10 \mathrm{~mL}$ of distilled water were placed in a flask, autoclaved, and then cooled down. The medium was then inoculated withIn this review, the biotechnological valorization of the BSG will be discussed. The various pretreatment methods applied for BSG to disrupt the natural resistance of the lignocellulose and to prepare the substrate for microbial activity-making it more accessible-were introduced. Then, submerged fermentation and solid-state fermentation methods were defined and discussed. The multiple value-added compounds produced via both types of fermentation were also described. T. versicolor. SSF occurred for 14 days at $27^{\circ} \mathrm{C}$, with a $63 \%$ initial moisture content. The highest laccase activity was produced after 7 days fermentation and it was equal to $560 \mathrm{U} / \mathrm{L}$ [68].

2-PE is another value-added molecule that can be produced through SSF of BSG. The SSF using Pichia kudriavzevii CECT 13,184 was carried out for $96 \mathrm{~h}$ in $500 \mathrm{~mL}$ Erlenmeyer flasks containing $95 \mathrm{~g}$ of pretreated and inoculated BSG. The highest concentration of 2-PE appeared after $10 \mathrm{~h}$ fermentation and at $30{ }^{\circ} \mathrm{C}$ and $76 \%$ initial content moisture, it was equal to $6.5 \mathrm{mg}^{2-} \mathrm{PE} / \mathrm{gds}$ in the presence of $4 \% \mathrm{~L}$-phenylalanine as precursor [69].

Ethanol is another alcohol that can be produced through SSF of BSG. SSF of pretreated (via diluted phosphoric acid) and enzymatically hydrolyzed BSG produced ethanol using S. cerevisiae for $72 \mathrm{~h}$ at $150 \mathrm{rpm}$ and $40{ }^{\circ} \mathrm{C}$. Actually, after $30 \mathrm{~h}$ fermentation, $5.1 \mathrm{~g}$ of ethanol were produced for every $100 \mathrm{~g}$ of BSG [12].

In addition, $\mathrm{GA}_{3}$ can be produced through SSF of BSG. Fermentation occurred in $500 \mathrm{~mL}$ flasks containing $50 \mathrm{~g}$ BSG in an enriched medium (containing glucose, $\mathrm{FeSO}_{4} \cdot 7 \mathrm{H}_{2} \mathrm{O}$, $\mathrm{MgSO}_{4}, \mathrm{MnSO}_{4} \cdot \mathrm{H}_{2} \mathrm{O}, \mathrm{ZnSO}_{4} \cdot 7 \mathrm{H}_{2} \mathrm{O}$, and at $\mathrm{pH}$ 5-5.5). The flasks were then autoclaved and inoculated using Fusarium fujikuroi IOC 4380, at a ratio equal to $15 \%$ to the mass of BSG. The highest $\mathrm{GA}_{3}$ production was achieved after $96 \mathrm{~h}$ of fermentation, at $28{ }^{\circ} \mathrm{C}$ and $80 \%$ moisture content, and was equal to $0.82 \mathrm{~g}$ per $\mathrm{kg}$ of BSG [70].

SSF of BSG using Aspergillus oryzae can also produce $\alpha$-amylase. Fermentation occurred in $250 \mathrm{~mL}$ Erlenmeyer flasks containing $5 \mathrm{~g}$ of BSG and a salt solution (composed of $\mathrm{NH}_{4} \mathrm{NO}_{3}, \mathrm{KH}_{2} \mathrm{PO}_{4}, \mathrm{NaCl}$, and $\mathrm{MgSO}_{4} \cdot 7 \mathrm{H}_{2} \mathrm{O}$ ). The substrate was then autoclaved and inoculated with $A$. oryzae NRRL 6270 . After $96 \mathrm{~h}$ fermentation at $30{ }^{\circ} \mathrm{C}$ and $70 \%$ moisture content, the maximum amount of $\alpha$-amylase produced by $A$. niger was $6870 \mathrm{U} /$ gds [71]. 
Finally, as previously discussed, BSG is a cost-effective carbon and nitrogen source that can be used as a substrate for microbial growth [53]. Through SSF on BSG, different microorganisms were able to produce various value-added compounds including cellulase, xylanolytic enzymes, laccase, 2-PE, ethanol, $\mathrm{GA}_{3}$, and $\alpha$-amylase.

\section{BSG Supply Chain System}

It was reported that around 3.4 and 4.5 million tons of BSG were produced from the brewing industry in Europe and the United States, respectively [14]. The huge quantities of BSG generated in the breweries, their low market value, their high moisture content associated with a difficulty in their storage, and their bad environmental effect made their disposal challenging [72]. The market price of BSG (40.23 USD/ton) is lower than the price of other cellulosic crops (between 50 and 150 USD/ton), which is mainly because BSG have high moisture content and are sold as is [14]. Formerly, large beer manufacturers used to install drying facilities to decrease the water content of the grains and make them more appealing for the farmers. However, most of the breweries are moving away from the drying process since it is expensive and energy-intensive [73]. A study done by Buffington suggested the usage of a "hub and spoke" model in order to integrate potential sellers and buyers of BSG. Therefore, the author proposed the creation of a network between different breweries and a bio-refinery (drying and storage of BSG), which will sell the BSG to biomass buyers that will manufacture them into the various useful products. Buffington assume that this proposition will increase the market price of BSG by $450 \%$ to reach 179.29 USD/ton [14]. More research should be done in order to develop the right supply chain structures for BSG and its economic market.

\section{Conclusions}

The increasing beer manufacturing nowadays leads to a corresponding increased accumulation of BSG that needs to be properly managed. BSG is the solid fraction remaining after wort removal [6]. It is nutritionally rich and composed of fibers, mainly hemicellulose, cellulose, and lignin, in addition to proteins, lipids, vitamins, and minerals [7]. However, due to the high moisture content and high polysaccharides and proteins contents, this byproduct is prone to microbial contamination within a few days of production; therefore, there is a need to find a suitable, economical, and environmentally friendly valorization method [2]. The biotechnological route of BSG valorization using SmF and SSF leads to the production of various value-added compounds [13]. To make the valorization process more efficient, a pretreatment step (e.g., chemical, physical, biological, hybrid, etc.) should precede the fermentation, in order to disrupt the natural recalcitrance of the lignocellulosic fibrous material of the BSG, exposing the polysaccharides, and making them more susceptible for enzymatic hydrolysis which aims to decompose them into fermentable sugars [74]. Finally, BSG can be processed into organic acids, amino acids, volatile fatty acids, vitamins, and second-generation biofuels [23] such as ethanol, citric acid, L-lactic acid, $\alpha$-amylase, cellulase, xylanolytic enzymes, laccase, 2-PE and $\mathrm{GA}_{3}$.

Author Contributions: S.M.: Investigation, Writing—original draft, Writing—review \& editing, Formal analysis. S.-J.S.: Writing—original draft, Writing—eview \& editing. A.K., E.L. and R.G.M.: Formal analysis, Writing—review \& editing. N.L. and M.K.: Conceptualization, Supervision, Writing-review \& editing, Formal analysis. All authors have read and agreed to the published version of the manuscript.

Funding: This research was funded by the Ministry of Higher Education, Research and Innovation in France, and by The Research Council of the Saint Joseph University of Beirut, in Lebanon FS-165.

Institutional Review Board Statement: Not applicable.

Informed Consent Statement: Not applicable.

Data Availability Statement: Not applicable.

Conflicts of Interest: The authors declare no conflict of interest. 


\section{References}

1. Oliver, G.; Colicchio, T. The Oxford Companion to Beer; The Oxford University Press: New York, NY, USA, 2011.

2. Patel, A.; Mikes, F.; Bühler, S.; Matsakas, L. Valorization of brewers' spent grain for the production of lipids by oleaginous yeast. Molecules 2018, 23, 3052. [CrossRef] [PubMed]

3. Parchami, M.; Ferreira, J.A.; Taherzadeh, M.J. Brewing process development by integration of edible filamentous fungi to upgrade the quality of brewer's spent grain (BSG). BioResources 2021, 16, 1686. [CrossRef]

4. Goberna, M.; Camacho, M.D.M.; Lopez-Abadia, J.A.; García, C. Co-digestion, biostimulation and bioaugmentation to enhance methanation of brewer's spent grain. Waste Manag. Res. 2013, 31, 805-810. [CrossRef] [PubMed]

5. The Brewers of Europe. European Beer Trends Statistics Report; The Brewers of Europe: Brussels, Belgium, 2019.

6. Kavalopoulos, M.; Stoumpou, V.; Christofi, A.; Mai, S.; Barampouti, E.M.; Moustakas, K.; Malamis, D.; Loizidou, M. Sustainable valorisation pathways mitigating environmental pollution from brewers' spent grains. Environ. Pollut. 2021, 270, 116069. [CrossRef] [PubMed]

7. Aprodu, I.; Simion, A.B.; Banu, I. Valorisation of the Brewers' Spent Grain Through Sourdough Bread Making. Int. J. Food Eng. 2017, 13, 20170195. [CrossRef]

8. Cooray, S.T.; Chen, W.N. Valorization of brewer's spent grain using fungi solid-state fermentation to enhance nutritional value. J. Funct. Foods 2018, 42, 85-94. [CrossRef]

9. Chetrariu, A.; Dabija, A. Brewer's spent grains: Possibilities of valorization, a review. Appl. Sci. 2020, 10, 5619. [CrossRef]

10. Cooray, S.T.; Lee, J.J.L.; Chen, W.N. Evaluation of brewers' spent grain as a novel media for yeast growth. AMB Express 2017, 7, 1-10. [CrossRef]

11. San Martin, D.; Orive, M.; Iñarra, B.; Castelo, J.; Estévez, A.; Nazzaro, J.; Iloro, I.; Elortza, F.; Zufía, J. Brewers' Spent Yeast and Grain Protein Hydrolysates as Second-Generation Feedstuff for Aquaculture Feed. Waste Biomass Valorization 2020, 11, 5307-5320. [CrossRef]

12. Rojas-Chamorro, J.A.; Cara, C.; Romero, I.; Ruiz, E.; Romero-García, J.M.; Mussatto, S.I.; Castro, E. Ethanol Production from Brewers' Spent Grain Pretreated by Dilute Phosphoric Acid. Energy Fuels 2018, 32, 5226-5233. [CrossRef]

13. Teixeira, M.R.; Guarda, E.C.; Freitas, E.B.; Galinha, C.F.; Duque, A.F.; Reis, M.A.M. Valorization of raw brewers' spent grain through the production of volatile fatty acids. New Biotechnol. 2020, 57, 4-10. [CrossRef] [PubMed]

14. Buffington, J. The Economic Potential of Brewer's Spent Grain (BSG) as a Biomass Feedstock. Adv. Chem. Eng. Sci. 2014, 4, 308-318. [CrossRef]

15. Mitri, S.; Koubaa, M.; Maroun, R.G.; Rossignol, T.; Nicaud, J.-M.; Louka, N. Bioproduction of 2-Phenylethanol through Yeast Fermentation on Synthetic Media and on Agro-Industrial Waste and By-Products: A Review. Foods 2022, 11, 109. [CrossRef] [PubMed]

16. Su, Y.; Du, R.; Guo, H.; Cao, M.; Wu, Q.; Su, R.; Qi, W.; He, Z. Fractional pretreatment of lignocellulose by alkaline hydrogen peroxide: Characterization of its major components. Food Bioprod. Process. 2015, 94, 322-330. [CrossRef]

17. Wilkinson, S.; Smart, K.A.; Cook, D.J. Optimising the (Microwave) Hydrothermal Pretreatment of Brewers Spent Grains for Bioethanol Production. J. Fuels 2015, 2015. [CrossRef]

18. Wang, H.; Tao, Y.; Temudo, M.; Bijl, H.; Kloek, J.; Ren, N.; van Lier, J.B.; de Kreuk, M. Biomethanation from enzymatically hydrolyzed brewer's spent grain: Impact of rapid increase in loadings. Bioresour. Technol. 2015, 190, 167-174. [CrossRef]

19. Gomes, M.M.; Rabelo, C.A.B.S.; Sakamoto, I.K.; Silva, E.L.; Varesche, M.B.A. Methane Production Using Brewery Spent Grain: Optimal Hydrothermolysis, Fermentation of Waste and Role of Microbial Populations. Waste Biomass Valorization 2021. [CrossRef]

20. Mussatto, S.I. Brewer's spent grain: A valuable feedstock for industrial applications. J. Sci. Food Agric. 2014, 97, 1264-1275. [CrossRef]

21. Kisielewska, M.; Rusanowska, P.; Dudek, M.; Nowicka, A.; Krzywik, A.; Dębowski, M.; Joanna, K.; Zieliński, M. Evaluation of Ultrasound Pretreatment for Enhanced Anaerobic Digestion of Sida hermaphrodita. Bioenergy Res. 2020, 13, 824-832. [CrossRef]

22. Baruah, J.; Nath, B.K.; Sharma, R.; Kumar, S.; Deka, R.C.; Baruah, D.C.; Kalita, E. Recent trends in the pretreatment of lignocellulosic biomass for value-added products. Front. Energy Res. 2018, 6, 141. [CrossRef]

23. Dávila, J.A.; Rosenberg, M.; Cardona, C.A. A biorefinery approach for the production of xylitol, ethanol and polyhydroxybutyrate from brewer's spent grain. AIMS Agric. Food 2016, 1, 52-66. [CrossRef]

24. Wilkinson, S.; Smart, K.A.; Cook, D.J. Optimisation of alkaline reagent based chemical pre-treatment of Brewers spent grains for bioethanol production. Ind. Crop. Prod. 2014, 62, 219-227. [CrossRef]

25. Brodeur, G.; Yau, E.; Badal, K.; Collier, J.; Ramachandran, K.B.; Ramakrishnan, S. Chemical and physicochemical pretreatment of lignocellulosic biomass: A review. Enzyme Res. 2011, 2011. [CrossRef] [PubMed]

26. Beldman, G.; Hennekam, J.; Voragen, A.G.J. Enzymatic hydrolysis of beer brewers' spent grain and the influence of pretreatments. Biotechnol. Bioeng. 1987, 30, 668-671. [CrossRef] [PubMed]

27. Jȩdrzejczyk, M.; Soszka, E.; Czapnik, M.; Ruppert, A.M.; Grams, J. Physical and chemical pretreatment of lignocellulosic biomass. In Second and Third Generation of Feedstocks: The Evolution of Biofuels; Elsevier: Amsterdam, The Netherlands, 2019; pp. 143-196. ISBN 9780128151624

28. Wagner, E.; Pería, M.E.; Ortiz, G.E.; Rojas, N.L.; Ghiringhelli, P.D. Valorization of brewer's spent grain by different strategies of structural destabilization and enzymatic saccharification. Ind. Crop. Prod. 2021, 163, 113329. [CrossRef] 
29. Aftab, M.N.; Iqbal, I.; Riaz, F.; Karadag, A.; Tabatabaei, M. Different Pretreatment Methods of Lignocellulosic Biomass for Use in Biofuel Production. In Biomass for Bioenergy-Recent Trends and Future Challenges; IntechOpen: London, UK, 2019.

30. Lynch, K.M.; Steffen, E.J.; Arendt, E.K. Brewers' spent grain: A review with an emphasis on food and health. J. Inst. Brew. 2016, 122, 553-568. [CrossRef]

31. Hassan, S.S.; Ravindran, R.; Jaiswal, S.; Tiwari, B.K.; Williams, G.A.; Jaiswal, A.K. An evaluation of sonication pretreatment for enhancing saccharification of brewers' spent grain. Waste Manag. 2020, 105, 240-247. [CrossRef]

32. Yu, Z.; Zhang, B.; Yu, F.; Xu, G.; Song, A. A real explosion: The requirement of steam explosion pretreatment. Bioresour. Technol. 2012, 121, 335-341. [CrossRef] [PubMed]

33. Menon, V.; Rao, M. Trends in bioconversion of lignocellulose: Biofuels, platform chemicals \& biorefinery concept. Prog. Energy Combust. Sci. 2012, 38, 522-550. [CrossRef]

34. Zheng, Y.; Lin, H.M.; Tsao, G.T. Pretreatment for cellulose hydrolysis by carbon dioxide explosion. Biotechnol. Prog. 1998, 14, 890-896. [CrossRef] [PubMed]

35. Zhuang, X.; Wang, W.; Yu, Q.; Qi, W.; Wang, Q.; Tan, X.; Zhou, G.; Yuan, Z. Liquid hot water pretreatment of lignocellulosic biomass for bioethanol production accompanying with high valuable products. Bioresour. Technol. 2016, 199, 68-75. [CrossRef] [PubMed]

36. Taylor, M.J.; Alabdrabalameer, H.A.; Skoulou, V. Choosing physical, physicochemical and chemical methods of pre-treating lignocellulosic wastes to repurpose into solid fuels. Sustainability 2019, 11, 3604. [CrossRef]

37. Puligundla, P.; Mok, C. Recent advances in biotechnological valorization of brewers' spent grain. Food Sci. Biotechnol. 2021, 30, 341-353. [CrossRef] [PubMed]

38. Bensah, E.C.; Mensah, M. Chemical pretreatment methods for the production of cellulosic ethanol: Technologies and innovations Int. J. Chem. Eng. 2013, 2, 887-898. [CrossRef]

39. Guarda, E.C.; Oliveira, A.C.; Antunes, S.; Freitas, F.; Castro, P.M.L.; Duque, A.F.; Reis, M.A.M. A two-stage process for conversion of brewer's spent grain into volatile fatty acids through acidogenic fermentation. Appl. Sci. 2021, 11, 3222. [CrossRef]

40. Marcus, A.; Fox, G. Fungal biovalorization of a brewing industry byproduct, brewer's spent grain: A review. Foods 2021, 10, 2159. [CrossRef] [PubMed]

41. Silbir, S.; Goksungur, Y. Natural red pigment production by monascus purpureus in submerged fermentation systems using a food industry waste: Brewer's spent grain. Foods 2019, 8, 161. [CrossRef]

42. Hölker, U.; Lenz, J. Solid-state fermentation-Are there any biotechnological advantages? Curr. Opin. Microbiol. 2005, 8, 301-306. [CrossRef]

43. Subramaniyam, R.; Vimala, R. Solid State and Submerged Fermentation for the Production of Bioactive Substances: A Comparative Study. Int. J. Sci. Nat. 2012, 3, 480-486.

44. Singhania, R.R.; Sukumaran, R.K.; Patel, A.K.; Larroche, C.; Pandey, A. Advancement and comparative profiles in the production technologies using solid-state and submerged fermentation for microbial cellulases. Enzyme Microb. Technol. 2010, 46, 541-549. [CrossRef]

45. Wolters, N.; Schabronath, C.; Schembecker, G.; Merz, J. Efficient conversion of pretreated brewer's spent grain and wheat bran by submerged cultivation of Hericium erinaceus. Bioresour. Technol. 2016, 222, 123-129. [CrossRef] [PubMed]

46. Srivastava, N.; Srivastava, M.; Ramteke, P.W.; Mishra, P.K. Solid-state fermentation strategy for microbial metabolites production: An overview. In New and Future Developments in Microbial Biotechnology and Bioengineering: Microbial Secondary Metabolites Biochemistry and Applications; Elsevier: Amsterdam, The Netherlands, 2019; ISBN 9780444635044.

47. Soccol, C.R.; da Costa, E.S.F.; Letti, L.A.J.; Karp, S.G.; Woiciechowski, A.L.; de Souza Vandenberghe, L.P. Recent developments and innovations in solid state fermentation. Biotechnol. Res. Innov. 2017, 1, 52-71. [CrossRef]

48. Doriya, K.; Jose, N.; Gowda, M.; Kumar, D.S. Solid-State Fermentation vs Submerged Fermentation for the Production of L-Asparaginase. In Advances in Food and Nutrition Research; Elsevier: Amsterdam, The Netherlands, 2016.

49. Hashemi, M.; Razavi, S.H.; Shojaosadati, S.A.; Mousavi, S.M. The potential of brewer's spent grain to improve the production of $\alpha$-amylase by Bacillus sp. KR-8104 in submerged fermentation system. New Biotechnol. 2011, 28, 165-172. [CrossRef] [PubMed]

50. Victor, A.; Titilayo, F.-O. Citric acid production from brewers spent grain by Aspergillus niger and Saccharomyces cerevisiae Enzymes from microorganisms isolated from insect gut View project Citric acid production from brewers spent grain by Aspergillus niger and Saccharomyces cere. Int. J. Res. Biosci. 2013, 2, 30-36.

51. Rachwał, K.; Waśko, A.; Gustaw, K.; Polak-Berecka, M. Utilization of brewery wastes in food industry. PeerJ 2020,8 , e9427. [CrossRef]

52. Shindo, S.; Tachibana, T. Production of L-lactic acid from spent grain, a by-product of beer production. J. Inst. Brew. 2004, 110, 347-351. [CrossRef]

53. Casas-Godoy, L.; González-Escobar, J.L.; Mathis, A.G.; Barrera-Martínez, I. Revalorization of untreated Brewer's spent grain: Novel and versatile feedstock to produce cellulases, lipases, and yeast biomass in a biorefinery approach. Biomass Convers. Biorefinery 2020, 1-12. [CrossRef]

54. Singh, M.; Devi, S.; Rana, V.S.; Mishra, B.B.; Kumar, J.; Ahluwalia, V. Delivery of phytochemicals by liposome cargos: Recent progress, challenges and opportunities. J. Microencapsul. 2019, 36, 215-235. [CrossRef]

55. Thomas, L.; Larroche, C.; Pandey, A. Current developments in solid-state fermentation. Biochem. Eng. J. 2013, 81, 146-161. [CrossRef] 
56. Pandey, A. Solid-state fermentation. Biochem. Eng. J. 2003, 13, 81-84. [CrossRef]

57. Krishna, C. Solid-state fermentation systems-An overview. Crit. Rev. Biotechnol. 2005, 25, 1-30. [CrossRef] [PubMed]

58. Rodríguez-Couto, S. Solid-State Fermentation for Laccases Production and Their Applications. In Current Developments in Biotechnology and Bioengineering; Elsevier: Amsterdam, The Netherlands, 2018; pp. 211-234.

59. Lima-Pérez, J.; López-Pérez, M.; Viniegra-González, G.; Loera, O. Solid-state fermentation of Bacillus thuringiensis var kurstaki HD-73 maintains higher biomass and spore yields as compared to submerged fermentation using the same media. Bioprocess Biosyst. Eng. 2019, 42, 1527-1535. [CrossRef] [PubMed]

60. Krishania, M.; Sindhu, R.; Binod, P.; Ahluwalia, V.; Kumar, V.; Sangwan, R.S.; Pandey, A. Design of Bioreactors in Solid-State Fermentation. In Current Developments in Biotechnology and Bioengineering; Elsevier: Amsterdam, The Netherlands, 2018; pp. 83-96.

61. Agarwal, A.K.; Agarwal, R.A.; Gupta, T.; Gurjar, B.R. Biofuels: Technology, Challenges and Prospects. In Green Energy and Technology; Springer: Berlin, Germany, 2017.

62. Salgado-Bautista, D.; Volke-Sepúlveda, T.; Figueroa-Martínez, F.; Carrasco-Navarro, U.; Chagolla-López, A.; Favela-Torres, E. Solid-state fermentation increases secretome complexity in Aspergillus brasiliensis. Fungal Biol. 2020, 124, 723-734. [CrossRef]

63. Hyseni, B.; Aytekin, A.Ö.; Nikerel, E. Solid state fermentation for enzyme production for food industry. J. Microbiol. Biotechnol. Food Sci. 2018, 7, 615-622. [CrossRef]

64. Costa, J.A.V.; Treichel, H.; Kumar, V.; Pandey, A. Advances in Solid-State Fermentation. In Current Developments in Biotechnology and Bioengineering; Elsevier: Amsterdam, The Netherlands, 2018; pp. 1-17.

65. Kumar, A.; Kanwar, S. Lipase production in solid-state fermentation (SSF): Recent developments and biotechnological applications. Dyn. Biochem. Process Biotechnol. Mol. Biol. 2012, 6, 13-27.

66. Moran-Aguilar, M.G.; Costa-Trigo, I.; Calderón-Santoyo, M.; Domínguez, J.M.; Aguilar-Uscanga, M.G. Production of cellulases and xylanases in solid-state fermentation by different strains of Aspergillus niger using sugarcane bagasse and brewery spent grain. Biochem. Eng. J. 2021, 6, 13-27. [CrossRef]

67. Terrasan, C.R.F.; Carmona, E.C. Solid-state fermentation of brewer's spent grain for xylanolytic enzymes production by penicillium janczewskii and analyses of the fermented substrate. Biosci. J. 2015, 31, 1826-1836. [CrossRef]

68. Tišma, M.; Jurić, A.; Bucić-Kojić, A.; Panjičko, M.; Planinić, M. Biovalorization of brewers' spent grain for the production of laccase and polyphenols. J. Inst. Brew. 2018, 124, 182-186. [CrossRef]

69. Martínez-Avila, O.; Muñoz-Torrero, P.; Sánchez, A.; Font, X.; Barrena, R. Valorization of agro-industrial wastes by producing 2-phenylethanol via solid-state fermentation: Influence of substrate selection on the process. Waste Manag. 2021, 121, 403-411. [CrossRef]

70. da Silva, L.R.I.; de Andrade, C.J.; de Oliveira, D.; Lerin, L.A. Solid-state fermentation in brewer's spent grains by fusarium fujikuroi for gibberellic acid production. Biointerface Res. Appl. Chem. 2021, 11, 13042-13052. [CrossRef]

71. Francis, F.; Sabu, A.; Madhavan Nampoothiri, K.; Szakacs, G.; Pandey, A. Synthesis of $\alpha$-amylase by Aspergillus oryzae in solid-state fermentation. J. Basic Microbiol. 2002, 42, 320-326. [CrossRef]

72. Assandri, D.; Pampuro, N.; Zara, G.; Cavallo, E.; Budroni, M. Suitability of composting process for the disposal and valorization of brewer's spent grain. Agriculture 2021, 11, 2. [CrossRef]

73. Landry, C. Beer for Bessie. Available online: https://www.perc.org/2002/12/01/beer-for-bessie/ (accessed on 10 December 2021).

74. Panjičko, M.; Zupančič, G.D.; Zelić, B. Anaerobic biodegradation of raw and pre-treated brewery spent grain utilizing solid state anaerobic digestion. Acta Chim. Slov. 2015, 62, 818-827. [CrossRef] [PubMed] 